\title{
DARI SUMBER INFORMASI KE GALERI PENGETAHUAN PENDEKATAN KEARSIPAN PADA PENYELENGGARAAN PAMERAN ARSIP STATIS
}

\author{
Adhie Gesit Pambudi, S. Sos, M.A. \\ Pejabat Struktural Eselon IV di lingkungan Sekretariat Utama ANRI \\ (g351t@yahoo.com)
}

\begin{abstract}
INTISARI
Dalam konsepsi kearsipan, pameran arsip statis sebenarnya bukan merupakan kegiatan fungsi inti dari sebuah lembaga kearsipan. Namun demikian, pameran arsip statis dapat memberikan manfaat yang besar bagi masyarakat. Hal ini dapat dicapai apabila pameran arsip statis dapat mentransformasikan arsip sebagai sumber informasi menjadi sumber pengetahuan. Penelitian ini mengelaborasi prinsip dan langkah-langkah yang harus dilakukan oleh lembaga kearsipan dalam penyelenggaraan pameran arsip statis yang nantinya dapat memberikan pengetahuan bagi masyarakat. Penelitian ini hanya membahas pada pendekatan kearsipan dalam penyelenggaran pameran arsip dan tidak membahas aspek lain seperti desain atau estetika.
\end{abstract}

Kata kunci: arsip statis, pemanfaatan arsip, pameran arsip statis

\begin{abstract}
Conceptually, archival exhibition is not a part of core functions of an archival organization. However, it could give an enormous benefit for the community when it could transform archives from just a source of information into a source of knowledge. This study elaborates principles and ideal stages that should be conducted by archival institution in organizing archival exhibitions so that it could give knowledge to the audiences. It focuses on a proper achival management approach in conducting archival exhibition rather than other aspects such as design or estetique.
\end{abstract}

Keywords: archives, archives publication, archival exhibition 


\section{PENGANTAR}

Dewasa ini, manfaat dari arsip khususnya arsip statis dapat dinikmati oleh masyarakat dari berbagai kalangan dan usia. Selain sebagai memori kolektif dan warisan dokumenter, arsip statis merupakan sumber primer dalam penulisan sejarah sebuah bangsa (Jeurgens, C, 2009). Arsip juga dijadikan sumber bahan pembelajaran di dunia pendidikan utamanya terkait mata pelajaran sejarah (Spraggs, G., 2008). Lembaga kearsipan sebagai insitusi kebudayaan yang memiliki fungsi pengelolaan arsip statis harus dapat menjaga kelestarian dan meningkatkan akses arsip statis kepada pengguna arsip (Rhee, H. L., 2015). Upaya yang dilakukan lembaga kearsipan dalam mempublikasikan khazanah arsip statis dilaksanakan dalam kegiatan pemanfaatan arsip statis yang salah satunya diselenggarakan melalui pameran.

Saat ini, pameran arsip statis sering dijadikan kegiatan unggulan dan populer yang diselenggarakan secara rutin oleh lembaga kearsipan (Howgill, E., 2015). Pameran arsip statis bahkan juga diselenggarakan di level internasional yang dilakukan melalui kerjasama yang melibatkan lembaga kearsipan dari berbagai Negara (Gelfand, A, 2013). Di sisi lain, pameran arsip statis dewasa ini tidak hanya disajikan secara langsung menggunakan etalase, tetapi juga seringkali ditayangkan melalui jaringan internet (Reid, G. A, 1996-2001).

Tujuan utama penyelenggaraan pameran arsip statis adalah untuk meningkatkan pengetahuan (to educate) kepada publik melalui penyajian khazanah arsip yang dimiliki lembaga kearsipan (Aubitz, S, et. al., 1990). Kegiatan pameran, arsip statis harus dapat bertransformasi dari sekedar sumber informasi (information) menjadi sumber pengetahuan (knowledge). Bahkan bukan tidak mungkin pameran arsip statis menjadi rujukan penulisan historiografi. Hal ini disebabkan karena pameran memiliki peran vital sebagai penghubung antara khazanah dan publik terutama dalam menyebarluaskan pengetahuan yang terkandung dalam arsip (Khoon, L.C., et. al, 2008).

Namun demikian, pameran arsip statis yang dilakukan oleh lembaga kearsipan tidak selalu dapat mencapai tujuan utamanya yaitu menjadikan arsip statis sebagai sumber pengetahuan. Kegagalan ini disebabkan karena kurangnya archival mind-set (pola pikir secara kearsipan) yang digunakan oleh penyelenggara pameran. Sementara itu, archival mind-set merupakan hal yang fundamental dalam penyelenggaraan pameran (Gordon, H, M. 1994). Hal lain penyebab kegagalan adalah penetuan target audiens yang kurang tepat yang kemudian mengakibatkan manfaat dari pengetahuan yang terdapat pada pameran tidak sampai ke pihak yang tepat (Lester, $P$, 2007). Pada proses penyajian, peran kurator yang tidak optimal dalam menyajikan konteks materi arsip juga menjadi penyebab kegagalan yang dominan (Edmonson, R., 2016).

Berdasarkan permasalahan pokok di atas, maka dapat diambil hipotesis bahwa pameran arsip statis memiliki peran dan manfaat yang besar bagi masyarakat. Namun demikian, apabila penyelenggaraannya yang tidak dilakukan secara benar, akan mengakibatkan tujuan utama pameran tidak tercapai. Lalu, bagaimana penyelenggaraan pameran arsip statis oleh lembaga kearsipan agar dapat menjadi sumber pengetahuan? Pembahasan pertanyaan tersebut akan diuraikan dalam tulisan ini.

Tujuan penelitian ini adalah meningkatkan pengetahuan dalam bidang pengelolaan arsip statis pada umumnya dan mengetahui penyelenggaraan pameran oleh lembaga kearsipan agar arsip statis dapat menjadi sumber pengetahuan pada khususnya. 
Penelitian ini diharapkan dapat memberikan manfaat kepada:

1. Arsip Nasional Republik Indonesia (ANRI) sebagai lembaga kearsipan nasional yang mengelola arsip statis di level nasional.

2. Lembaga Kearsipan Provinsi, Kabupaten/Kota, dan Perguruan Tinggi yang mengelola arsip statis sesuai dengan wilayah kewenangannya.

3. Arsiparis sebagai profesional di bidang kearsipan khususnya yang melakukan pengelolaan arsip statis.

4. Kurator sebagai profesional di bidang permuseuman dan penyelenggaraan pameran.

\section{Metodologi Penelitian}

Penelitian ini merupakan jenis penelitian kualitatif yang pada umumnya berusaha mengkonstruksi realitas dan memahami makna serta sangat memperhatikan proses, peristiwa dan otentisitas. Adapun paradigma yang digunakan adalah konstruktivis dengan pendekatan deskriptif. Teknik pengumpulan data yang digunakan dalam penelitian ini adalah studi terhadap sumber pustaka buku, artikel jurnal, dan peraturan perundang-undangan.

Dalam pembahasan, ruang lingkup penelitian ini dibatasi pada aspek-aspek substansi kearsipan dalam upaya peningkatan kualitas substansi penyelenggaraan pameran arsip statis. Penelitian ini tidak akan membahas faktor-faktor lain seperti teknik komunikasi, estetika, desain dan hal lainnya yang berada di luar lingkup kearsipan (archivistiek).

\section{Kerangka Pemikiran}

\begin{tabular}{lrrr}
\multicolumn{2}{c}{ Penelitian ini } & \multicolumn{2}{c}{ menggunakan } \\
berbagai teori sebagai & dasar dalam \\
menyusun & kerangka & pemikiran \\
penulisan. & Dalam & ilmu & kearsipan \\
(archival science), arsip & memiliki \\
pengertian & yang & sangat & beragam
\end{tabular}

(Dryden, J. 2004). Definisi arsip bisa merujuk kepada dokumen/fisik arsip, unit kearsipan, organisasi kearsipan, profesi kearsipan, bangunan penyimpanan arsip, atau koleksi publikasi ilmiah (Pearce-Moses, 2005). Menurut Undang-Undang Nomor 43 Tahun 2009 tentang Kearsipan, arsip merupakan rekaman kegiatan atau peristiwa dalam berbagai bentuk dan media sesuai dengan perkembangan teknologi informasi dan komunikasi yang dibuat dan diterima oleh lembaga negara, pemerintahan daerah, lembaga pendidikan, perusahaan, organisasi politik, organisasi kemasyarakatan, dan perseorangan dalam pelaksanaan kehidupan bermasyarakat, berbangsa, dan bernegara.

Arsip statis (archives) menurut Undang-Undang Nomor 43 Tahun 2009 memiliki pengertian sebagai arsip yang dihasilkan oleh pencipta arsip karena memiliki nilai guna kesejarahan, telah habis retensinya, dan berketerangan dipermanenkan yang telah diverifikasi baik secara langsung maupun tidak langsung oleh ANRI dan/atau lembaga kearsipan. Pengelolaan arsip statis merupakan proses pengendalian arsip statis secara efisien, efektif, dan sistematis meliputi akuisisi, pengolahan, preservasi, pemanfaatan, pendayagunaan, dan pelayanan publik dalam suatu sistem kearsipan nasional. Menurut The Society of American Archivists (SAA), pengelolaan arsip statis adalah pengelolaan umum terhadap program untuk melakukan penilaian dan akuisisi, pengaturan dan deskripsi, preservasi, autentikasi, dan menyediakan akses terhadap arsip yang bernilai guna permanen (Gosh, M, 2010).

Menurut Pearce-Moses, pameran merupakan sebuah penyajian materi yang terorganisasi (Pearce-Moses, 2005). Sedangkan pameran arsip statis merupakan kegiatan yang dilakukan oleh lembaga kearsipan dalam rangka mempublikasikan khazanah arsip yang 
dimiliki (Lester, P, 2007). Pameran dapat digolongkan sebagai jenis akses arsip statis secara proaktif karena pada umumnya penyelenggaraannya diprakarsai oleh lembaga kearsipan (Edmonson, R., 2016:24).

Pameran menjadi alat untuk menggugah ketertarikan publik terhadap khazanah arsip, memperluas audiens, dan meningkatkan kesadaran masyarakat terhadap warisan budaya dokumenter mereka (Lerette, B. T., 2002:8). Namun demikian, pameran arsip statis bukan merupakan bagian dari fungsi inti (core functions) dari lembaga kearsipan dalam melakukan pengelolaan arsip statis. Keberhasilan penyelenggaraan berbagai kegiatan pameran arsip akan menjadi tidak berarti (meaningless) apabila sebuah lembaga kearsipan gagal dalam melaksanakan kegiatan akusisi, pengolahan, preservasi, dan layanan akses arsip statis yang merupakan core functions lembaga kearsipan (Gordon, $\mathrm{H}$, M. 1994:4-5). Namun demikian, hal ini tidak menjadikan pameran arsip statis sebagai kegiatan pelengkap. Pameran arsip statis dapat menjadi kegiatan strategis apabila kehadirannya dapat memberikan pengetahuan kepada pengunjung sekaligus mendorong penyerahan arsip statis oleh entitas pencipta arsip, pengolahan arsip statis, peningkatan preservasi arsip statis, dan penyediaan akses dan layanan arsip statis.

Pameran arsip statis memiliki karakteristik tersendiri dibandingkan dengan pameran yang diselenggarakan oleh Museum dan Perpustakaan. Perbedaan yang paling menonjol adalah pameran kearsipan tidak boleh meninggalkan prinsip dasar kearsipan yaitu provenance dan original order. Berbeda dengan arsip, museum menggunakan pendekatan collection policy dan obyek budaya sebagai dasar penyelenggaraan pameran dengan isu original dan provenance tidak menjadi faktor determinan. Berbeda dengan kedua saudaranya, pameran perpustakaan lebih mengutamakan pendekatan tema daripada provenance karena kerakteristik bahan pustaka yang bervariasi (Gordon, H, M. 1994:31).

\section{ANALISIS DAN PEMBAHASAN Tujuan Utama: Memberikan Pengetahuan}

Pada dasarnya setiap penyelenggaraan kegiatan dalam bentuk apapun, pelaksanaannya harus sesuai dengan tujuan yang ditetapkan sebelumnya. Tujuan ini sangat berpengaruh pada penentuan tema yang akan digunakan dan target audiens yang akan menjadi sasaran kegiatan. Demikian pula dengan pameran arsip statis, tujuan pameran ini biasanya ditentukan oleh manajemen dan harus benar-benar didefinisikan jelas dan konkret. Adapun tujuan utama (primary objective) dari setiap penyelenggaraan pameran arsip statis adalah memberikan pengetahuan (knowledge) kepada pengunjung yang mendatangi galeri pameran (Keith, $\mathrm{P}$, 2014:29). Sebuah pameran harus dapat memberikan kontribusi terhadap ilmu pengetahuan terkait dengan sejarah dan warisan budaya bangsa (Khoon, L.C., et. al, 2008:9). Tujuan ini harus selalu menjadi landasan fundamental penyelenggaraan pameran arsip statis.

Ketika sebuah pameran arsip statis tudak dapat menjawab tujuan utama, maka esensi penyelenggaraannya menjadi tidak berarti. Hal ini disebabkan tujuan pemanfaatan arsip statis adalah menyajikan arsip statis dari yang bersifat informasi menjadi sebuah pengetahuan bagi pengunjung. Pameran tidak hanya sekedar menampilkan material arsip, tetapi semestinya mengilustrasikan atau menggambarkan gagasan atau sebuah proses yang terjadi di balik keberadaan material tersebut. Lebih jauh, pameran harus dapat memberikan pemahaman kepada pengunjung tentang materi yang 
dipamerkan dan hubungannya dengan kehidupan mereka.

Namun demikian, untuk dapat mengubah informasi arsip menjadi pengetahuan dalam bentuk pameran bukan merupakan hal yang mudah. Memberikan pengetahuan kepada masyarakat khususnya tentang masa lampau melalui penerbitan naskah sumber, misalnya akan jauh lebih mudah karena narasi yang dituliskan dapat membentuk pengetahuan pembaca.

Selain memberikan pengetahuan kepada pengunjung sebagai tujuan utama, pameran arsip statis secara praktis juga bertujuan untuk meningkatkan peran lembaga kearsipan sebagai pengelola arsip statis. Oleh karena itu, pameran arsip statis hendaknya dapat meningkatkan kesadaran penyerahan arsip statis ke lembaga kearsipan. Dengan demikian, kegiatan pameran memiliki peran dalam mendukung kegiatan akusisi oleh lembaga kearsipan. Kegiatan pameran harus dapat menciptakan efek persuasif kepada masyarakat khususnya pencipta arsip untuk menyerahkan arsip statis ke lembaga kearsipan. Hal ini dilakukan dengan cara menyajikan arsip hasil akuisisi sebagai penghargaan kepada pencipta arsip yang menyerahkan arsip mereka kepada lembaga kearsipan (Rabins, J, 1980:31).

Pameran arsip statis dapat mendorong kegiatan pengolahan arsip statis oleh lembaga kearsipan. Hal ini disebabkan proses penelusuran materi dalam rangka pameran sangat bertumpu pada kualitas sarana penemuan kembali arsip statis yang dihasilkan dari kegiatan pengolahan arsip statis. Semakin banyak khazanah yang sudah diolah dan memiliki sarana penemuan kembali, maka akses terhadap khazanah arsip statis lembaga kearsipan menjadi semakin tinggi.

Penyelenggaraan pameran arsip statis juga dapat meningkatkan kualitas penyelenggaraan kegiatan preservasi arsip statis. Kualitas fisik dan informasi materi arsip statis yang ditampilkan dalam pameran bisa menggambarkan performa lembaga kearsipan dalam melakukan preservasi arsip statis seperti penyimpanan, restorasi, digitalisasi, dan risk assesment. Hal ini disebabkan kondisi arsip merupakan syarat mutlak bagi lembaga kearsipan untuk menampilkan arsip statis dalam pameran.

Penyelenggaraan pameran juga diharapkan mendorong penggunaan arsip statis oleh pengguna arsip dalam rangka penelitian dan riset. Oleh sebab itu, semestinya pameran juga dapat meningkatkan jumlah kunjungan ke ruang baca dan peminjaman arsip statis di lembaga kearsipan. Pameran adalah wahana yang dapat memotivasi manusia untuk belajar tentang masa lalu dan sejarah. Dengan demikian, tidak salah apabila penyelenggaraan pameran arsip statis dapat mempengaruhi penulisan historiografi sebuah bangsa.

Namun demikian, lembaga kearsipan juga tidak dilarang untuk menentukan tujuan lain setelah tujuan utama. Lembaga kearsipan dapat menentukan tujuan lain (secondary objectives) yang hendak dicapai dalam penyelenggaraan pameran seperti menjadikannya sebagai alat diplomasi kebudayaan (cultural diplomacy), sarana hiburan (entertainment), pengenalan/pengakuan (acknowledgement), pencitraan (imaging), pengenalan tentang kearsipan statis (archival works), dan lain-lain.

\section{Penentuan Jenis Pameran: Konsepsi Dasar}

Hal yang paling mendasar yang dilakukan pada persiapan penyelenggaraan pameran adalah menentukan jenis pameran yang akan dilaksanakan. Secara konseptual menurut Heather Marrie Gordon, terdapat empat jenis pameran yang dapat 
diselenggarakan oleh lembaga kearsipan antara lain: (Gordon, H, M. 1994:40-110)

\section{Pameran Tematis}

Pameran jenis ini sangat sering diselenggarakan oleh lembaga kearsipan ataupun museum. Secara garis besar, pameran tematis bertujuan untuk memberikan pengetahuan kepada pengunjung tentang sebuah subjek/tema tertentu dari perspektif sejarah. Di sisi lain, pameran tematis juga harus dapat menyajikan alur cerita yang menarik namun disajikan dengan mempertimbangkan nilai-nilai secara intelektual. Pameran tematis menitikberatkan pada subjek/tema tertentu yang dibatasi oleh ruang lingkup yang ditentukan oleh lembaga kearsipan. Ruang lingkup ini menjadi batasan yang digunakan dalam menentukan materi dan teknik penyajian yang digunakan dalam pameran. Batasan yang dapat digunakan dalam pameran tematis dapat berupa topik, kurun waktu, lokasi geografis, peristiwa, tokoh, dan indikator lain yang dianggap spesifik oleh lembaga kearsipan. Karena sifatnya yang spesifik, lembaga kearsipan harus dapat menghindari untuk menampilkan materi-materi yang memungkinkan sebuah pameran keluar dari tema yang diusung.

\section{Pameran Peringatan}

Pameran arsip statis jenis ini dilaksanakan untuk memperingati sebuah peristiwa dalam sejarah. Pemeran ini juga digunakan untuk merayakan hari jadi sebuah organisasi atau merayakan hari besar baik yang bersifat kenegaraan, keagamaan, dan lain sebagainya. Pameran ini menitikberatkan pada peristiwa atau kejadian di masa lalu yang menjadi tonggak sejarah sehingga layak diberikan penghormatan oleh generasi masa kini. Tantangan terbesar bagi lembaga kearsipan dalam menyelenggarakan pameran ini adalah menentukan teknik penyajian materi yang menarik terhadap hal yang bersifat rutin diperingati setiap tahunnya. Oleh sebab itu, lembaga kearsipan harus dapat eksplorasi terhadap khazanah arsip yang dimiliki dan menampilkannya dengan metode yang baru agar tidak terjadi kebosanan bagi para pengunjung. Namun demikian, hal yang perlu diperhatikan oleh lembaga kearsipan dalam menyelenggarakan pameran peringatan adalah menghindari pemilihan materi yang cenderung mengangkat subjek sejarah yang berkaitan dengan hal yang diperingati/dirayakan. Hal ini akan menimbulkan kebingungan bagi para pengunjung karena jenis pameran akan cenderung berubah menjadi tematis.

3. Pameran Institusional

Pameran ini digunakan untuk mempromosikan lembaga kearsipan sebagai pengelola arsip statis dan khazanah arsip statis yang dimiliki. Hal yang membedakan pameran jenis ini dengan pameran kelembagaan pada umumnya adalah pada tujuannya yaitu untuk meningkatkan pengetahuan masyarakat tentang khazanah arsip statis yang diakuisisi, diolah, dipreservasi, dan dilayankan oleh lembaga kearsipan. Salah satu contoh dari pameran ini adalah pameran yang menampilkan khazanah arsip statis milik sebuah lembaga kearsipan yang baru saja diakuisisi (new acquisition). Hal ini menunjukkan peran lembaga kearsipan sebagai penyelamat dan pelestari memori kolektif bangsa. Pameran ini juga menekankan pada penyebarluasan informasi tentang misi organisasi dan kegiatan kearsipan tertentu. Namun 
demikian, pameran jenis ini pada umumnya hanya menarik untuk kalangan tententu. Untuk audiens yang tidak memiliki kepentingan dengan lembaga kearsipan atau dunia kearsipan, pameran ini cenderung membosankan. Oleh sebab itu, lembaga kearsipan yang menyelenggarakan pameran jenis ini harus dapat mengemas informasi yang disajikan agar timbul ketertarikan dari pengunjung dan dapat memberikan pengetahuan kepada audiens.

4. Pameran Fungsional

$\begin{array}{llr}\begin{array}{c}\text { Pameran } \\ \text { menitikberatkan }\end{array} & \text { jenis } & \text { ini } \\ \text { penyebarluasan } & \text { informasi } & \text { dan }\end{array}$
pengetahuan kepada masyarakat tentang kegiatan kearsipan yang dilakukan oleh lembaga kearsipan. Salah satu aspek utama yang sering diangkat dalam pameran ini adalah pengelolaan arsip statis yang dilaksanakan oleh lembaga kearsipan. Selain itu, pameran ini juga dapat mengangkat peran arsiparis dalam penyelenggaraan kearsipan. Sama halnya dengan pameran institusional, pameran jenis ini pada umumnya hanya menarik untuk kalangan tententu yang memiliki kepentingan dengan lembaga kearsipan atau dunia kearsipan, pameran ini cenderung tidak menarik bagi masyarakat secara umum.

\section{Penentuan Target Audiens: Segmentasi}

Penentuan/spesifikasi target audiens atau publik sasaran menjadi kunci keberhasilan sebuah pameran arsip statis. Target audiens akan muncul setelah tujuan penyelenggaraan pameran ditentukan. Diversifikasi publik sasaran oleh lembaga kearsipan dapat dilakukan dengan berdasarkan latar belakang usia, pendidikan, pekerjaan, geografis, dan lain sebagainya. Sebuah pameran arsip statis tidak akan dapat menjangkau seluruh jenis khalayak (Lester, P, 2007:9). Oleh sebab itu, lembaga kearsipan harus menentukkan target audiens yang tersegmentasi (segmented audience).

Lembaga kearsipan sebaiknya tidak mencampur target audiens yang memiliki perbedaan atau karekteristik yang menonjol. Sebuah pameran yang memiliki target audiens kalangan profesional tertentu seperti klub pengacara kemungkinan besar materinya tidak akan sesuai apabila pameran tersebut dikunjungi oleh kalangan pelajar dari usia sekolah dasar. Oleh karena itu, lembaga kearsipan juga akan menyesuaikan tempat dan waktu penyelenggaraan pameran sesuai dengan kebutuhan target audiens (Khoon, L.C., et. al, 2008:8).

\section{Penyusunan Storyline (Alur Cerita): Milestone Sejarah}

Perlu ditekankan bagi lembaga kearsipan, penyelenggaraan pameran arsip statis bukanlah merupakan kegiatan yang instan dan sederhana. Dibutuhkan proses intelektual yang tajam agar tujuan utama penyelenggaraan pameran dapat tercapai yaitu mengubah informasi menjadi pengetahuan. Tema yang diangkat dalam pameran arsip statis berkaitan dengan sejarah atau kejadian di masa lampau. Oleh sebab itu, lembaga kearsipan harus merekonstruksi tema yang ditentukan melalui sebuah storyline yang disusun berdasarkan timeline sejarah (Gordon, S.T, 2008:38). Dengan demikian, terciptalah konteks yang dapat menceritakan arsip yang akan ditampilkan secara kronologis dari perspektif sejarah. Penyusunan storyline dilakukan dengan mempertimbangkan aspek milestone dari segala peristiwa yang terjadi dalam sejarah yang berkaitan 
yang akan diangkat. Pengetahuan konteks perspektif kesejarahan ini dapat diperoleh melalui riset yang ilmiah dengan menggunakan berbagai sumber dari mulai arsip, bahan pustaka, dan terbitan sejaman. Dalam penyusunan storyline harus terdapat starting point dan ending point yang jelas karena hal ini merupakan ruang lingkup tema atau peristiwa yang disajikan.

Selain aspek sejarah, penyusunan storyline juga mempertimbangkan perspektif kearsipan utamanya terkait dengan pencipta arsip (creating agencies) yang terlibat dalam tema yang diangkat. Dengan demikian, pameran arsip statis juga mempertimbangkan principle of provenance (prinsip asal usul) dalam proses penyelenggaraannya (Gordon, H, M. 1994:34).

\section{Penelusuran Materi Arsip: Sistematis dan Komprehensif}

Dalam penyelenggaraan pameran, lembaga kearsipan harus melakukan penelusuran materi arsip statis secara sistematis dan komprehensif. Oleh karena itu, pengetahuan yang mendalam (tidak hanya bersifat umum) terhadap khazanah arsip statis (archival holdings) yang dimiliki oleh sebuah lembaga mutlak harus dimiliki. Pengetahuan tentang khazanah arsip statis tidak dapat didapatkan secara instan. Perlu pendekatan sistematis untuk bisa memahami kekayaan khazanah arsip statis sebuah lembaga kearsipan. Hal pertama yang harus diketahui adalah skema pengaturan khazanah arsip statis di sebuah lembaga kearsipan (arrangement in the depository level). Lembaga kearsipan pada umumnya melakukan pengaturan arsip statis sesuai dengan kebutuhan dan kebijakan yang mereka tetapkan. Pengaturan arsip statis di sebuah lembaga biasanya dilakukan secara kronologis, hierarkis, level organisasi, ataupun kombinasi dari beberapa sistem tersebut (Holmes, O. W, 1964:24).

Selain itu, penelusur harus memahami jenis-jenis sarana penemuan kembali yang dimiliki oleh lembaga kearsipan seperti inventaris, daftar arsip, dan guide arsip statis. Tidak hanya itu, penelusur harus memahami relasi antara sarana penemuan kembali tersebut (Yakel, E., 2003:65). Untuk dapat melakukan penelurusan arsip yang efektif, penyelenggara pameran harus mengetahui fungsi dari setiap pencipta arsip yang khazanah arsip statisnya terdapat di lembaga kearsipan. Fungsi tersebut akan menjelaskan jenis arsip yang tercipta dari pencipta arsip tersebut. Oleh sebab itu, diperlukan pengetahuan tentang administrasi pemerintahan dari periode arsip yang tertua hingga yang terbaru.

Selain itu, pengetahuan lain yang dibutuhkan dalam penelusuran arsip dalah tentang sistem kearsipan yang digunakan dalam khazanah arsip statis. Dengan pengetahuan tentang sistem kearsipan yang mendalam, proses penemuan kembali akan menjadi semakin cepat. Pengetahuan dasar tentang konsepsi records group, fonds, series, files, dan item yang diterapkan pada sarana penemuan arsip statis merupakan aspek fundamental yang harus dimiliki untuk menelusur arsip dalam rangka pameran (Holmes, O. W, 1964:25).

\section{Penyeleksian Materi Pameran: Imparsialitas}

Kesalahan terbesar yang sering dilakukan oleh lembaga kearsipan adalah pada proses penyeleksian arsip hasil penelusuran yang kemudian akan ditampilkan dalam pameran. Pada umumnya, lembaga kearsipan sering mengesampingkan bahwa pameran arsip statis dapat mempengaruhi penulisan sejarah dan historiografi ataupun opini masyarakat tentang suatu peristiwa atau 
fenomena tertentu dalam sejarah. Lebih jauh, hal ini dapat mempengaruhi pembentukan karakter dan budaya bangsa (Keteelar, E., 2007:344).

Proses seleksi arsip yang akan dipamerkan harus benar-benar dilakukan dengan mempertimbangkan berbagai aspek seperti fakta sejarah, imparsialitas, self-censorhip dan sebagainya. Selain itu, penyeleksian arsip harus dilakukan dengan tidak hanya mempertimbangkan tampilan sebuah arsip yang terlihat lebih menarik daripada arsip yang lainnya. Penyeleksian arsip juga sebaiknya dilakukan oleh seseorang yang memiliki pengetahuan sejarah dan kearsipan yang kuat khususnya terkait tema yang diangkat untuk dapat disajikan secara sistematis dan metodologis melalui pertimbangan konsepsi historiografis (Gelfand, A, 2013:54).

\section{Penyajian Arsip: Tidak Mengandalkan Deskripsi}

Tujuan untuk pemberikan pengetahuan harus dipegang teguh dalam penyelenggaraan pameran arsip statis. Oleh sebab itu, teknik penyajian arsip tidak hanya mempertimbangkan aspek estetika. Aspek utama yang harus diperhatikan adalah penyajian informasi arsip. Semakin lengkap informasi yang disajikan dalam pameran maka pengetahuan yang diperoleh pengunjung akan semakin meningkat.

Hal yang perlu diperhatikan adalah arsip tidak dapat bercerita ketika ia berdiri sendiri tanpa disertai konteks. Oleh karena itu, biasanya arsip ditampilkan beserta keterangan yang memberikan pengetahuan bagi pengunjung. Pada umumnya, lembaga kearsipan hanya mengandalkan deskripsi arsip yang terdapat pada sarana penemuan kembali arsip statis baik berupa daftar, inventaris atau guide arsip statis. Namun, perlu disadari bahwa sarana penemuan kembali tersebut hanya menyajikan informasi arsip belum menjadi sebuah pengetahuan.

Hal lain yang perlu diperhatikan adalah penyusunan sarana penemuan kembali arsip statis dilakukan oleh arsiparis yang berpedoman pada konteks penciptaan, proses administrasi lembaga pencipta, dan sistem kearsipan yang digunakan. Oleh sebab itu, konteks yang muncul dalam deskripsi adalah konteks secara kearsipan. Untuk dapat meningkatkan status deskripsi dari sekedar informasi menjadi sebuah pengetahuan, perlu adanya tambahan keterangan yang disusun dengan mempertimbangkan aspek sejarah sesuai dengan jenis dan tema yang diangkat dalam pameran agar pengunjung tidak mengalami kebingungan secara kontekstual. Oleh sebab itu, peran dari arsiparis sebagai kurator pameran arsip statis dalam menginterpretasikan konteks sangat tinggi (Edmonson, R., 2016:25).

\section{KESIMPULAN}

Dari analisis dan pembahasan yang dilakukan terhadap hasil dari penelitian, maka dapat disimpulkan beberapa hal sebagai berikut:

1. Pameran arsip statis bukan merupakan core function bagi lembaga kearsipan. Namun demikian, keberadaaannya dapat memberikan manfaat yang sangat besar untuk masyarakat ataupun lembaga kearsipan apabila penyelenggaraannya dilakukan melalui proses yang sesuai dengan prinsip-prinsip dan kaidah kearsipan serta dibekali dengan pengetahuan kesejarahan yang kuat.

2. Penyelenggaraan pameran arsip statis harus selalu berpegang teguh pada tujuan utama yaitu memberikan pengetahuan kepada pengunjung dan tidak hanya bersifat informasional.

3. Penyelenggaraan pameran memberikan dampak yang luar biasa bagi masyarakat dan penulisan 
sejarah. Oleh sebab itu, lembaga kearsipan harus benar-benar mempertimbangkan segala faktor yang mempengaruhi dalam proses penyeleksian materi pameran baik yang datang dari luar atau dari dalam organisasi.

4. Penyelenggaraan pameran memperhatikan berbagai aspek seperti tema yang jelas secara ruang lingkup, audiens yang tersegmentasi, penelusuran yang sistematis, penyeleksian yang mempertimbangkan aspek sejarah dan imparsialitas, serta penyajian yang memperhatikan aspek kontekstual.

Dari kesimpulan tersebut, maka dapat direkomendasikan beberapa hal sebagai berikut:

1. Setiap tahapan penyelenggaraan pameran harus dilaksanakan secara sistematis dan sesuai dengan kaidah kearsipan agar tujuan pameran untuk memberikan manfaat pengetahuan bagi pengunjung dapat tercapai sekaligus memberikan dampak positif terhadap pengelolaan arsip statis yang dilakukan oleh lembaga kearsipan.

2. Penyelenggaran pameran sebaiknya melibatkan SDM Kearsipan yang memiliki kompetensi tinggi tidak hanya dalam bidang sejarah, tetapi juga menguasai sistem kearsipan baik di masa lalu maupun masa kini.

\section{DAFTAR PUSTAKA}

Aubitz, S, et. al., 1990, Developing Archival Exhibitions, Technical Leaflet Series, Number 5 (USA: Mid-Atlantic Regional Archives Conference).

Dryden, J. 2004. "What's in a Word: The Fuzziness of Archival Terminology”, Journal of Archival
Organization, Vol. 2(1/2), 2004. (USA: The Haworth Press). p. 147-151.

Edmonson, R., 2016, Audiovisual Archiving: Philosopy and Principles (Paris: UNESCO)

Gelfand, A, 2013, "If We Build It (and Promote It) They Will Come: History of Analog and Digital Exhibits in Archival Repositories", Journal of Archival Organization, Vol. 11, Issue. 1-2, p. 49-82.

Gordon, S.T, 2008, "Heritage, Commerce, and Museal Display: Toward a New Typology of Historical Exhibition in the United States”, The Public Historian, Vol. 30, No. 3, p. 27-50.

Gosh, M, 2010, Archives and e-records management in Canada: a state of the art report (Canada: The York University).

Holmes, O. W, 1964, “Archival Arrangement Five Different Operations at Five Different Levels", The American Archivist, Vol. 27, No. 1, p. 21-42.

Howgill, E., 2015, "New methods of analysing archival exhibitions", Archives and Records, Vol.36, No. 2, p. 179-194.

Jeurgens, C, 2009, “Archieven tussen geschiedenis, erfgoed, en volkenkunde", Archievenblad, September 2009, p. 28-30.

Keith, P, 2014, Folding the Exhibition, (Barcelona: MACBA)

Keteelar, E., 2007, "Muniments and monuments: the dawn of archives as cultural patrimony”, 
Archivaria, Vol. 7, Issue 4, p. 343357.

Khoon, L.C., et. al, 2008, “An Overview of Online Exhibitions”, DESIDOC Journal of Library and Information Technology, Vol. 28, No. 4, July 2008, p. 7-21.

Lester, P, 2007, “Is the virtual exhibition the natural successor to the physical?", Journal of the Society of Archivists, Vol. 27, Issue 1, p. 85-101.

Pearce-Moses, 2005,R. A Glossary of Archival and Records Terminology (Chicago: The Society of American Archivist).

Rabins, J, 1980, “Archival Exhibits: Considerations and Caveats", Georgia Archive, Vol. 8, No. 2, pp. 29-40.

Reid, G. A "Digital Exhibition: The Powys Digital History Project, 1996-2001”, Journal of the Society of Archivists, Vol. 22, Issue. 2, p. $161-176$.

Rhee, H. L., 2015, "Reflections on Archival User Studies”, Reference and User Services Quarterly, June 2015, p. 29-42.

Spraggs, G., 2008, Using Archives in Higher Education History Teaching, (Somerset: Society of Archivists)

Yakel, E., 2003, “AI: Archival Intelligence and User Expertise”, The American Archivist, Vol. 66 (Spring/Summer 2003), p. 51-78.

\section{Thesis:}

Gordon, H, M. 1994. Archival Exhibition: Purposes and
Principle, MA Thesis (Vancouver: University of British Columbia).

Lerette, B. T., 2002, Archival Materials Exhibited in an Art Museum: A Case Study of Museum-Library Collaboration, Master Thesis (USA: University of North Carolina at Chapel Hill)

\section{Peraturan:}

Undang-Undang Nomor 43 Tahun 2009 tentang Kearsipan

Peraturan Pemerintah Nomor 28 Tahun 2012 tentang Pelaksanaan UndangUndang Nomor 43 Tahun 2009 tentang Kearsipan 